\title{
The Vacant Utopia: Reflecting on the First Polish Post-war Staging of The Tempest
}

\author{
Przemysław Pożar
}

\begin{abstract}
In 1947 Leon Schiller staged The Tempest as his first post-war Shakespeare play. From today's perspective, his choice possibly reveals the intention to counter the harshness of post-war reality or to display a sense of an unbroken connection to pre-war efforts. However, the inherent utopianism of The Tempest coupled with all too fervent championing of his own theatrical theory laid bare the vanity of Schiller's endeavours. Furthermore, the new translation of the play turned out defective, as it was found to be coalesced with the 19th century canonical Polish version. Schiller's partisan aspirations raise additional doubts as to his motivations. Several central ideas of the play were lost in this staging, leaving one to doubt whether the utopic character of the play was been contaminated by the new hope the Soviet regime brought with it. Reviewing this production of The Tempest can provide insights into an interim period when cultural processes in Poland were moulding, a new Polish Shakespearean canon was but anticipated, and Kott's Shakespeare, Our Contemporary (1964) had yet to enter the stage.
\end{abstract}

\section{Key words}

The Tempest, Shakespeare, Polish post-war theatre

This article incorporates the research results of the state-funded project The e-Repository of the Polish 20th and 21st Century Shakespeare Translations: Resources, Strategies and Reception 2018-2021 (NCN Opus 14 2017/27/B/HS2/00853). 
Leon Schiller, a renowned Polish director of the interwar period, staged The Tempest in 1947 in Łódź, an industrial city with an ambition to become a cultural centre in the Communist Poland. The apparent aim of the production was to reclaim the spectacular visual style of Schiller's pre-war productions, and thereby to re-establish a pattern of continuity following the atrocities of the war. Additionally, a new translation of The Tempest (Burza) was commissioned from Czesław Jastrzębiec-Kozłowski, possibly as a result of the call for a revision of the canon of translations voiced by Polish Shakespeareans of the time. And yet the ambitious enterprise soon sunk into oblivion, with contemporary reviews often entangled in political rather than critical disputes. Among Shakespeare scholars today, none but a few uphold the intellectual value of the staging. This verdict is rendered even more conspicuous if juxtaposed with the uniquely strong reception of Schiller's last pre-war rendition of The Tempest (1938) directed at the Jewish Folks un Jungt-Teater in Łódź in a production pulsating with a shattering political message about the inevitable surge of brutish anti-humanist forces. Nevertheless, the inherent utopianism of The Tempest coupled with the fervent championing of his own theatrical theories laid bare the lack of congruence of Schiller's first post-war encounter with Shakespeare.

Emil Cioran argues in History and Utopia that people 'act only under the fascination of the impossible: which is to say that a society incapable of generating - and of dedicating itself to - a utopia is threatened with sclerosis and collapse' (CIORAN 2015: 83-84). In what follows, I will argue that Schiller's 1947 production of The Tempest is an act at variance with Cioran's declaration. Its utopic character is rendered hollow and artificial, as is testified to by the director's rather heedless transposition of the scenographical tools implemented in the previous production. Schiller's 1947 The Tempest is thus made into a blithe utopia that, contrary to the assertion of the Romanian philosopher, leaves the audience oblivious to the memory and tragedy of events of the recent past.

\section{Historical background}

To be able to validate this thesis, however, it is crucial to bear in mind that our understanding of the immediate post-war period in Eastern Europe can easily suffer from oversimplifications caused by the ensuing grip of Stalinism. Thus, earlier political tendencies (including those aiming at the reconstruction of the pre-war order or negotiating new 'capitalist' covenants) can become dwarfed or neglected entirely in view of what now may seem inevitable. Our sense of entropy and foreboding regarding the period may be further facilitated by the obscurity of the sources from the post-war era. Indeed, it was not until the death of Stalin in 1953 that the Khrushchev Thaw allowed artists from behind the Iron Curtain more freedom and a chance for increased and enhanced exchanges of cultural experiences among nations in the newly relaxed climate.

Notwithstanding a preoccupation with Stalinism which may prevent us from sketching out an extensive account of the artistic endeavours and formation processes that 
occurred in this period, the significance of these processes can be made more apparent with time. In the effort to shed light on the years prior to the Thaw beginning with the end of the Second World War, the term interim will be here introduced and applied throughout the following analysis to isolate and validate this period in terms of its importance for the cultural tendencies and artistic responses to the trauma of the recently ended war along with the political uncertainty of the immediate future.

In his history of literature in Poland, Czesław Miłosz (1983) devotes close attention to the social reaction to the provocations of the Communist system as it was being implemented:

In order to understand how public opinion reacted to the new setup, one should keep in mind the utter exhaustion after the war and the terrible bloodletting. The country had to be rebuilt. The London government-in-exile was compromised because it had lost its political game, which had been staked upon the United States and England. And it must be acknowledged that if the Nazi plan for exterminating the Poles as an 'inferior race' had failed, it was primarily because of the heroism of the Red Army. Moreover, Poland's new border on the Oder River could be protected only by the Soviet Union against probable future German claims. (MIŁOSZ 1983: 449)

Additionally, Miłosz provides a nuanced analysis of the post-war period in Polish literature by giving an overview of the first two decades following war's end (MIŁOSZ 1983: 453). What we call here the interim period (1945-1953) is divided by Miłosz into two timespans, with the first interval lasting until 1949 'marked by debates on what literature should be in a country aiming at socialism' (MIŁOSZ 1983: 453). During this time writers could enjoy 'considerable liberalism' as they were left to probe the boundaries of a newly established censorship which thus far had introduced only few stringent regulations (MIŁOSZ 1983: 453). This can be contrasted with the second 'period from 1949 until the end of 1955 [which] left few books deserving of attention' (MIŁOSZ 1983: 453) due to the enforcement of the doctrine of Socialist Realism.

With regard to the interim, Zdeněk Stř́ibrný indicates in his succinct account of Shakespeare's influence on Eastern Europe how the authorities of the Soviet Union's satellite states viewed the English playwright quite enthusiastically, although naturally the reception of his works came under increased scrutiny (STǨ́́BRNÝ 2000: 97). Specifically, it was the Bard's prestige that was seen as a promoting factor for the establishment of new educational institutions within the Communist Bloc, i.e. the schools and academies were in need of recognisable source material to be appropriated within the framework of social realism. As Stř́ibrný claims:

Of all playwrights, Shakespeare was the most attractive for theatres, schools, and research institutes because he represented the highest artistic value approved by Marx and Engels themselves. Even the dyed-in-the-wool apparatchiks did not dare to attack him openly, although they found it personally offensive to hear from Hamlet that something was rotten in the state of Denmark. (STŘ́́BRNÝ 2000: 87) 
This interim should be then understood as a period characterised by an intellectual effort to reclaim lives and careers frustrated by the Second World War facilitated by relative ease of cultural control by the Soviet authorities in the years immediately following the war. This effort, moreover, laid the foundation for the artistic practices in the years subsequent to the Thaw. Although the term may appear discouragingly broad, it may be useful in terms of reflecting upon and problematizing the appreciation of Leon Schiller's first post-war staging of The Tempest in Łódź in 1947. After sketching out a portrayal of the Polish director based on Anna Chojnacka's recent account ${ }^{1}$ as well as an older biography written by Edward Csató, ${ }^{2}$ the paper seeks to claim that the ethical and aesthetic complexity of Schiller's effort to stage Shakespeare during the interim period resulted in a success of highly disputable nature.

\section{Leon Schiller and his monumental theatre}

Leon Schiller would have likely needed no introduction to a resident of Poland during the later interwar period. Renowned artist, propagator of Gordon Craig's theatrical practices, and armchair leftist, ${ }^{3}$ Schiller was one of the first directors who attempted to conspicuously draw upon the history and aesthetics of Polish theatre. Schiller struggled to establish ideological and aesthetic conventions for a 'grand' national institution as a founder of 'Polish monumental theatre.' Although Schiller's views ceaselessly fluctuated in his attempts to adapt to the ideological turbulence of the first decades of the $20^{\text {th }}$ century, his ideas can be generally characterised in this short introduction.

Despite the fact that Schiller and Gordon Craig collaborated, the term monumental theatre does not come from the Craig's vocabulary (KUCHTÓWNA 2000: 17); nevertheless, Schiller was clearly inspired by his older collaborator (CSATÓ 1968: 20). The

1 See (CHOJNACKA 2015) and earlier biography by (ROGACKI 1995).

2 I was made aware of Csató via a master's thesis by Gabriela Łazarkiewicz (2013), who wrote on the theatrical reconstructions of Caliban in the $20^{\text {th }}$ and $21^{\text {st }}$ century in Poland. This thesis developed into an article by Łazarkiewicz about two Polish stagings of The Tempest in Slovak translation by Jana Bžochová-Wild. See (ŁAZARKIEWICZ 2015).

3 According to Csató, Schiller's upbringing should have led him away from communism rather than towards it. However, the biographer argues that it is early twentieth century commercialism that pointed Schiller to less aesthetically restrictive left. It is also important to restate after Csató that by adhering to this world view Schiller had to be aware of difficulties this decision might have caused him (CSATÓ 1968: 20-21).

4 Although Csató mistakenly ascribes the coinage of the term monumental theatre to Craig, his remarks on what it entails ought to be briefly quoted: 'the theatre was supposed to be common, identified with rural audiences, and especially with the working-class' ('teatr miat być popularny, zwiazany z publicznościa ludowa, przede wszystkim robotnicza'). It is also important to bear in mind that Schiller's views were initially inspired by the German Freie Volksbuhne, a view which was 'far from the concept of propagandist theatre, that had as its goal cultivation of the Marxist world view through artistic endeavours' ('daleka byta od koncepcji teatru propagandowego, uważajacego za swój cel wpajanie marksistowskiego pogladu na świat poprzez działalność artystyczna') (CSATÓ 1968: 20). All English translations are by the author of the article. 
concept seems to have referred to the architectural denotation of the word monumental, a term contrasting the structural lavishness of churches with the comparative simplicity of a parlour in a domestic residence, suggesting that theatre should aim for the former (RASZEWSKI 1961: Introduction XI). Though Schiller radically opposed Craig's idea of the 'temple-theatre', ${ }^{5}$ the Pole voiced 'a nostalgia towards the grandeur of the old European tragedy, ${ }^{6}$ thus hinting not only at the sheer dimensions of the theatrical scene, but also at the ideal thematic composition of a play (RASZEWSKI 1961: Introduction XI). However, as time passed and Schiller's thought developed, his theories became somewhat convoluted. Along with the development of the political theatre in the West in 1930s, monumental theatre transformed in Schiller's view into a revolutionary theatre, an institution socially engaged and standing for the struggling classes.

According to some contemporary scholars, the definition of the term introduces an insurmountable problem due to its historical specificity (FIK 2000: 201). The concept appears to never have effloresced into a coherent theoretical structure. Its character though can be distinguished more precisely by identifying the opposites. Marta Fik attempts thus to enumerate what the monumental theatre is not and arrives at no less than two observations of particular importance to this discussion. Firstly, monumental plays ought not to give any thought to the mundane, nor are they to put forward any postulates typical of the naturalistic or realistic theatre. Interestingly, one of its core tenors - to resist the avant-garde - was notoriously neglected by Schiller, who envisioned his stages by drawing inspiration from the malleability of experimental arts (FIK 2000: 199). Secondly, within the scope of Schiller's concept there was no room for intimacy, nor for any attempts to psychologize the characters or render them politically meaningful, although plays themselves politically engaged could bear various aspects of 'monumentality' (FIK 2000: 199-200).

Fik posits that traces of such a theatre are almost nowhere to be found after the Second World War (FIK 2000: 201). Moreover, whatever was left of its premises was supposed to be turned into a monumental socialist theatre, a process taking place as Schiller was simultaneously striving not only to implement his vision, but also render his work compliant with the new regime (KRASIŃSKI 2000: 206). His decision to join the ruling party and pursue a political career were met with the approval of the regime, as the authorities were in constant search for eminent individuals who could serve to legitimize the new leadership (CHOJNACKA 2015: 226).

\footnotetext{
$5 \quad$ Timoszewicz (1989: 136) points out that this was perhaps the only bone of contention between Craig and Schiller, one which nevertheless clearly divided the two politically, as Schiller posited that the aim of the theatre is to serve the working class.

6 'Doszta w niej do gtosu nostalgia za wielkościa dawnej europejskiej tragedii $i$ wtedy “monumentalny” znaczyto zarazem wymiar sceny i zakres przedstawianej treści.' (RASZEWSKI 1961: Introduction XI)
} 


\section{Comrade Schiller}

Chojnacka traces Schiller's left-wing sympathies, which were coupled, oddly enough, with an ardent advocacy for Christian faith and values, to his teenage years and a fascination with the revolutionary character of Polish Romantic tradition, where sensitiveness to social injustice was intertwined with a strong desire for liberation (CHOJNACKA 2015: 217; TIMOSZEWICZ 1989: 140) ${ }^{7}$. An eager proponent of a 'theatre for the masses', when Schiller became the director of Boguslawski's Theatre in Warsaw in 1924 he introduced diverse social and educational activities to complement the stagings. Chojnacka observes that his productions were not yet engaged with Communism during the interwar period, but they did show evidence of a candid engagement with social issues (CHOJNACKA 2015: 219). It was not until 1928 that Schiller started mingling with Communist intellectuals, and even financially supporting a Communist newspaper for several subsequent years (CHOJNACKA 2015: 221). The following decade saw Schiller not only thriving as a director, but also strengthening his ties with the pro-Soviet group, forming a relationship which from time to time caused him some minor inconvenience but never hindered his career (CHOJNACKA 2015: 223-225). During the Second World War, Schiller joined the committee of an underground theatre council which deliberated on the shape the Polish theatre would take after the conflict (CHOJNACKA 2015: 226). However, aside from Schiller's political plans for a Communist future, it is also crucial to consider the director's traumatic experience of Auschwitz and his torture at the hands of Nazi soldiers, an ordeal which severely damaged Schiller both physically and mentally (ROGACKI 1995: 131). The repercussions of that incident are never referred to directly in Schiller's writings, but his subsequent devotion to Christianity and his relentlessness in bringing the theories of monumental theatre to ultimate fruition can arguably be seen as a self-administered therapeutic yet ruminative response to the horror of the war trauma.

When the conflict was over, Schiller found himself abroad, a situation which fledgling Communist propagandists took advantage of, as his urge to return to Poland provided a great opportunity to create favourable publicity for the new regime, as is shown in newspaper articles that formally welcomed Schiller back in 1946 (CHOJNACKA 2015: 230). ${ }^{8}$ On 21 June 1946, Leon Schiller - the coryphaeus of the new theatre - officially became a member of the Polish Worker's Party (PPR).

Interestingly, the director's ideological subservience never meant parting with what he considered tradition. Despite the refreshed civic vocation, monumental theatre remained imbued with strong Romantic tendencies, a propensity which entails, as the leading Polish Romantic Adam Mickiewicz would have it, that drama, like all art, should encompass and demonstrate the entirety of the poetic endeavours of the nation, and

7 As Timoszewicz (1989: 140) indicates 'Schiller was fascinated with Mickiewicz's shouting at the pope: "... be aware that the Spirit of God resides now within the rags of Parisian workers".'

8 See also Chojnacka (2015: 12) and the timeline entry - 2. 1. 1946. The title of the article goes as follows: 'Leon Schiller wants to build a magnificent and community-oriented theatre for the masses'. 
that works should preferably end with a prophecy (MICKIEWICZ 1998: 166). It could be said of Schiller that he was at the same time fascinated by the theatrical avant-garde and also mindful of the history of Polish theatre. Thus, Schiller's preoccupation with theorising led him not only to put forth self-contradictory postulates, but also to create a paradigm in which plays had to be selected meticulously to fit into his particular framework. The inherent eclecticism of his art can be seen as both his hallmark and an impediment, an observation corroborated by his 1968 biographer, who suggests that 'Schiller's programme, when confronted with reality, turned out to be too substantial, i.e. utopic [emphasis added] in a sense ${ }^{9}$ (CSATÓ 1968: 483). This suspicion finds additional corroboration in Csató's division of Schiller's artistic career into four periods based on director's interests and approaches. Of particular importance to the present paper is the fourth period of Csató's division, within which 'Schiller attempts to ameliorate the synthesis of his earlier theatrical endeavours and negotiate a concordance with at that time operative (and officially accepted by Schiller) aesthetics of social realism.' Provided the post-war The Tempest can be seen as a part of that striving, it becomes somewhat easier to understand why - as we will see - the production is steeped in contradictions. Moreover, the struggle to synthesise, and the notion of synthesis as such, appears to be Schiller's lifelong yet futile effort. Reflecting upon the director's favourite conceptions of the theatre, Csató observes that there never was any coherence between them, they did not appear in harmony, nor did they strike with enough intensity in any of Schiller's productions so that it could be called programmatic.

As a consequence, Schiller chose to work with the canonical texts, both Polish and international, including the plays by William Shakespeare which constituted a source of immense inspiration for both Romantics and neo-Romantics of the interwar period, a stance which created consequences for the propagators of monumental theatre (FIK 2000: 198; TERLECKI 2000: 9). Schiller was aware of Shakespeare's privileged (but regressively Romanticised) position on the Polish theatrical scene, ${ }^{10}$ and had tried to revolutionise it already before the Second World War, which is especially evident in his interpretation of The Tempest from this period.

\section{Shakespeare's and Schiller's utopia}

Utopia is a place at odds with existence itself, a paragon-state on the outskirts of the world. In her characterization of the concept, Fátima Vieria (2010) argues that its transience constitutes its quiddity: '[...] from the very beginning of the history it showed a facility for acquiring new meanings, for serving new interests, and for crystalizing

$9 \quad$ '... program Schillera okazat sie przy przymierzeniu do rzeczywistości zbyt obszerny, to znaczy w pewnym sensie utopijny.' (CSATÓ 1968: 483)

10 Shakespeare was still heavily romanticised, with neither stage translations nor others published during the interwar period betraying any considerable signs of modernisation of the idiolects of the Bard's characters. Canonical translations still prevailed, perhaps showing regressive preferences of both practitioners and audiences. 
into new formats' (VIERIA 2010: 6). Further, Vieria posits after Ernst Bloch that utopia's essential quality is hope (VIERIA 2010: 7). The concept is then to be understood as 'a matter of attitude, as a kind of reaction to an undesirable present and an aspiration to overcome all difficulties by the imagination of possible alternatives' (VIERIA 2010: 7).

Characters that call into question the undesirable present are certainly represented in Shakespeare's The Tempest. Not only can one attest this claim by pointing to Caliban and his struggle to remove the tyrannical Prospero from power or Gonzalo's somewhat ludicrous and scarcely credible vision of the island, but also by closely examining the structure of the play. ${ }^{11}$ What is more, Thomas Bulger (1994) suggests in his article that the sheer extent of the endeavours pertaining to a radical and idealistic alteration of the current political paradigm in the play allows it to be considered as an effort to make a mockery of utopia (BULGER 1994: 39). In Bulger's view, the very first scene of The Tempest proposes a faux attempt to undermine the political status quo of England's $16^{\text {th }}$ century monarchy, as the action "presents a view of the commonwealth that does not simply and blindly affirm the orthodox royal ideology of Jacobean England, but instead has a more egalitarian bent' (BULGER 1994: 38). It is surely a striving of utopic blend to question the state of prevailing politics, yet a conflict must precede such an attempt as 'the old order of things must be temporally suspended, spatially removed, or both' (BULGER 1994: 38). This view is corroborated by Cetera (2012) in the critical introduction to the most recent Polish translation of Shakespeare's The Tempest: 'a clash between the Old and the New World is inscribed within Prospero's plan'12 (CETERA 2012: 15). Additionally, Bulger provides an interesting gloss on the play's title, worth quoting at length:

The tempest points to a world where time is out of joint, where individuals because of the life-threatening circumstances of the storm no longer feel obligated to traditional social conventions and hierarchies, where individuals are at odds with the physical cosmos, where preexisting structures are rent or rendered inoperative. For human existence to continue, harmony needs to be (re)established on the personal, social, and cosmic levels. (BULGER 1994: 38)

In the beginning of the play Prospero's island seems to be an unspoiled space devoid of wicked or villainous schemes. The thaumaturge employs his enchanted volumes to teach as he exercises his authority to pass seemingly benevolent judgements onto those deserving punishment (BULGER 1994: 39). However, this perspective is soon called into question as Prospero is revealed to exert tyrannical power, revealing him as a manifestation of Plato's autocratic philosopher. Bulger comments on how scenes in Act II present 'false or incomplete views on utopianism' and, furthermore, 'illustrate human

11 In his article 'The Utopic Structure of The Tempest', Thomas Bulger facilitates his analysis with a Freytag Pyramid depicting each stage of the play's realisation of the utopian framework (BULGER 1994: 46n13).

12 '... konfrontacja Starego i Nowego Świata wyznacza pole gry dla Prospera.'(CETERA 2012: 15) 
faults and foibles that prohibit the achievement of utopian contentment on a grand scale' (BULGER 1994: 40).

The false utopia of Act II finds its counteract in Act III, just as a move from microcosmic to macrocosmic utopia is achieved by combining Acts IV and V (BULGER 1994: 41-43). The characters of the play attempt to bring to fruition various utopian concepts, but scarcely any achieves that task. Caliban seems to be here the ultimate sufferer, as his potential reformation is kept within bounds despite the apparently positive conclusion of Act V. Thus, as Bulger claims with regard to the utopic fabric of the play, 'the Communalism and Communism of the golden age is a wonderful ideal to entertain and to strive for but also a serious delusion if regarded as a spatio-temporal historical reality' (BULGER 1994: 44).

As Jan Kott argues throughout Shakespeare, Our Contemporary, the Bard's plays are able to render the decisive moments in history pregnant with meaning (KOTT 1990: 81). His scornful remark that Schiller's 1947 Shakespeare production was too focused on the aesthetics serves the Polish critic to prove that The Tempest is also permeated with a feeling of historical finality. ${ }^{13}$ It is the ultimate onstage "journey into the unknown' ${ }^{14}$ and, as the unwritten imperative would have it, every conclusion demands a new beginning. Although, the notion of a fresh start is only alluded to by Prospero, the potential implications of his ambiguous 'I'll drown my books' in Act V, Scene 1 (SHAKESPEARE 2011: 288) ${ }^{15}$ allows for a spectrum of adaptations which might hint at the dawn of a new historical era. Coupled with the critique of utopia carved into the play's fabric, its eschatological aspects make the play a particularly apt vehicle to illustrate and problematize periods of political turmoil.

Of all Shakespeare's plays, it was The Tempest which appealed to Schiller most, both before and after the Second World War. Quoting Csató, Lazarkiewicz points to the formative function of Shakespeare's utopia in Schiller's 'emotional mythology'16 already in very early years of the director's artistic career.

[T]here occurred in [Schiller's] mind a symbolical mergence (the word 'identification' perhaps would have been more fitting, but insufficiently subtle) between the astonishing phenomenon of the theatrical metamorphosis and the properties of Prospero's magical staff. Caliban must have appeared to him as a dark, extorted from the entrails of earth, and moulded with arch-materialistic clay, negation of fantasy's miraculous flight [...] Caliban's resentful bloody hatred towards Prospero [...] became over time an embodiment of revolution, a rebellion of the masses driven to extremes ${ }^{17}[\ldots]$ (CSATÓ 2000: 363)

13 See (KOTT 1990: 330-381).

14 'For Shakespeare [as a stage practitioner], The Tempest could have also been a journey into the unknown, a rendezvous with the new aesthetics.' ('Dla Shakespeare'a Burza mogta być również wyprawa w nieznane, flirtem z nowa estetyka.') (CETERA 2012: 16)

15 All the quotations from the play are taken from the Arden Shakespeare Edition, $3^{\text {rd }}$ edition of 2011.

16 'emocjonalna mitologia' (qtd. in ŁAZARKIEWICZ 2013: 46; following CSATÓ 1968: 363).

17 'Od poczatku dokonato sie w jego umyśle symboliczne potaczenie (stowo 'identyfikacja' bytoby tu może prostsze, ale nie dostatecznie subtelne) zadziwiajacego zjawiska teatralnej metamorfozy z dziataniem magicznej laseczki Prospera. 
This interpretation appears to set itself against the play's comic dynamics, hence suggesting Schiller's contemporary political awareness and causing him to see in Caliban a symbol of the proletariat, i.e. an epitome of the argument against the subjugation of the working class. Indeed, Schiller's strongly politicised slant on Prospero and Caliban confirms not only his preoccupation with the play, but also his will to reform the theatre. ${ }^{18}$

Consequently, two characteristic features of Schiller's endeavours as a theatrical visionary emerge. Firstly, Schiller attempted to bring Polish theatre closer to the masses of the common people and render it politically responsive while simultaneously revealing Romantic tendencies hindered by the regime up until 1955. Secondly, and perhaps more to the point of the present discussion, Schiller was preoccupied with the utopic dimension of The Tempest, a perspective which fit into his idea of revolution, therefore serving to embody and enhance his Marxist world view.

\section{The Tempest of 1947}

But what happens when this vision, one based on pre-war leftist sympathies and fuelled by the post-war opportunity to bring them to fruition, can be confronted with the reality of post-Yalta Poland?

As Łazarkiewicz indicates, Schiller's concept of The Tempest called for the employment of the motifs of medieval morality play, leaving a bare minimum of props on the stage so that the director could achieve the effect of 'naïve realism' (CSATÓ 1968: 46; POPIEL 1995: 235), a concept which coincides with Schiller's idea of the monumental theatre. The question then emerges as to whether other notions of the director's conceptual framework can be discerned from the surviving records of the performance.

One of a series of photographs of the production (see Fig. 1.) featured on the website e-teatr.pl shows Prospero on a scale which is set on what appears to be a ramp erected above the proper stage. The set piece will not be entered upon by any other human character except Prospero, elevating the thaumaturge and his magical properties. Moreover, thanks to a backdrop featuring the ring of a compass that hangs from above and encircles the rightful Duke of Milan, he can be easily kept in focus by the audience. Prospero is here proud and Shakespeare-like, quite elaborately attired and holding a wooden pointer directed at the map onto which inscribed are images

Kaliban musiat mu się wtedy przedstawiać jako ciemne, z wnętrzności ziemi wyszarpane, z arcymaterialistycznej gliny ulepione zaprzeczenie cudownego lotu fantazji [...] Zapiekta, krwawa nienawiść Kalibana do Prospera [...] stata sie z czasem obrazem rewolucji, porywu doprowadzonych do ostateczności mas ludowych.' (CSATÓ 1968: 363)

18 Csató discusses Schiller's 1928 manifesto article in which the director postulates not merely a theatre to appease the masses, but a strictly proletarian theatre that should curb its tendencies toward aestheticism in general to a bare minimum and reject bourgeoisie aestheticism altogether (CSATÓ 1968: 23-24). What is more, Csató adds in the biography that Schiller's subsequent position as the director of the theatre in Lviv (modern Ukraine) would in fact not allow for the fruition of the aforementioned project, as the people of Polish Eastern Borderlands, and Lviv in particular, would have probably objected to Marxist propaganda (CSATÓ 1968: 32). 


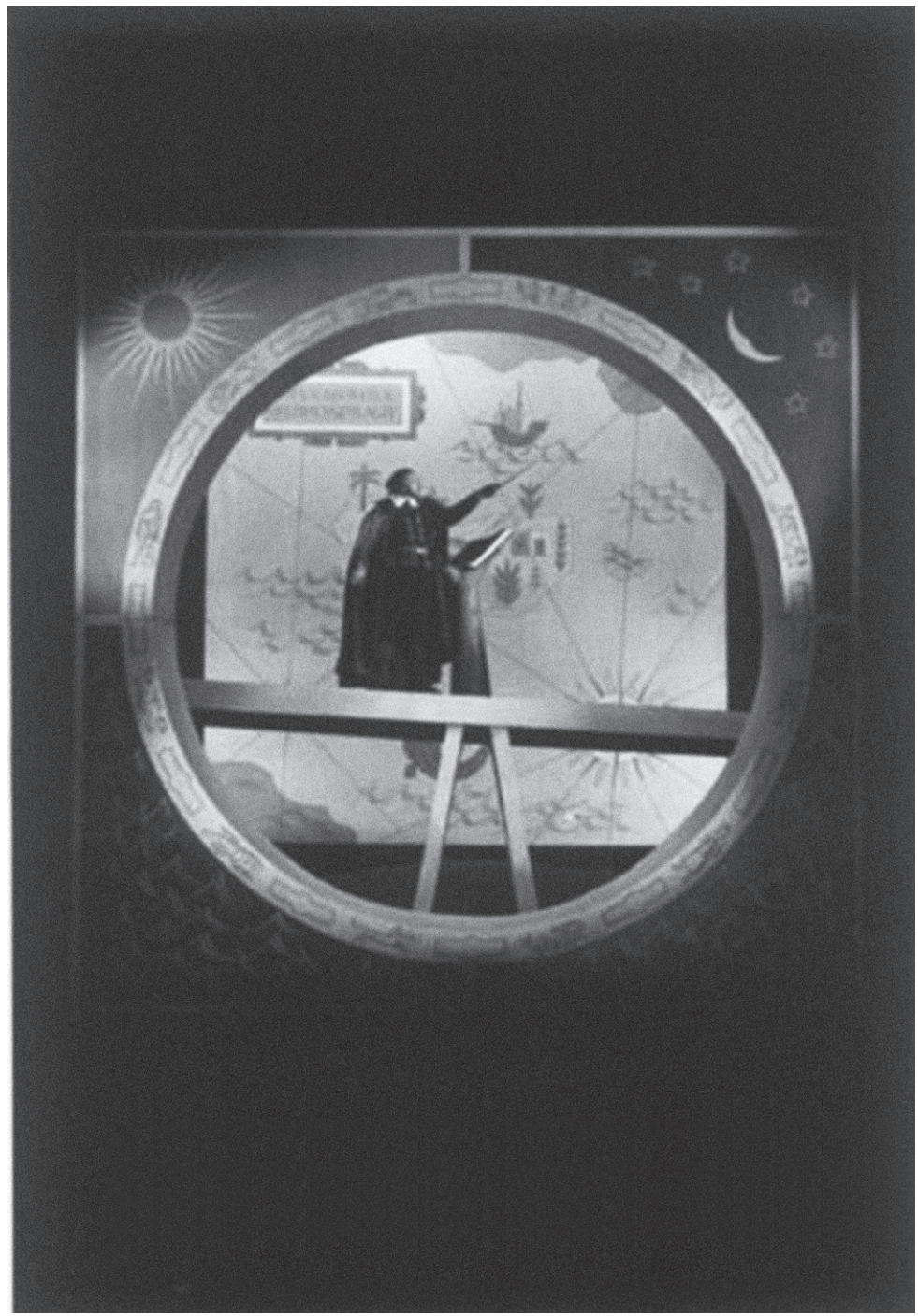

Fig. 1: Stanisław Brzozowski and Jan Malarski: The Tempest (direction: Leon Schiller). Teatr Wojska Polskiego (Theatre of the Polish Army), Łódź, 1947.

Nine more photographs from the production by Stanisław Brzozowski and Jan Malarski can be accessed online at: http://www.e-teatr.pl/pl/realizacje/20517,szczegoly.html. Accessed 13.12.2019. The photographs are stored in the archives of The Aleksander Zelwerowicz National Academy of Dramatic Art in Warsaw.

of the island along with Prospero's hut and the sea - a peculiar metanarrative tool. The lights are dimmed, with only the upstage area lit. The anti-naturalistic properties of monumental theatre are evident in this tableau. Firstly, the grandeur with which Prospero presents his story to the audience (Miranda is nowhere to be seen; perhaps she sits somewhere listening in the dark or underneath the ramp) coincides 
with what Jacek Popiel considers to be one of the founding elements of the realisation of Schiller's concept in performance, namely that 'the monumental theatre can be distinguished by its immense scenographical scope, a constant urge to negotiate material, technical and directorial limitations' (POPIEL 1995: 233). ${ }^{19}$ Moreover, Popiel observes that the unrealistic monumental visuals can be described as alluding to syncretism and symbolism in general in the fine arts (POPIEL 1995: 234). This postimpressionistic feature is also present in the 1947 production in the figure of the map, which strikingly serves as the backdrop throughout the entire play.

Apart from the visual records, several audio recordings of the play can be found in the Polish National Digital Archives ${ }^{20}$ through which another characteristic of the play explored in Schiller's theoretical approach can be tracked. Popiel remarks that 'the exaltedness, hieraticness and monumentality can be related to the practices and style of acting in the monumental theatre'21 (POPIEL 1995: 238). And indeed, whether it is Caliban telling the history of his slavedom, Prospero's epilogue, or the fragments of solemn music that accompany the text, both the actors and the devices remind us with quite unabated passion that this drama more often than not crosses the generic boundaries of a comedy and enters the hieratic realm of tragedy. The quality of Prospero's voice in Schiller's 1947 production was assessed by contemporary newspaper reviewer Karolina Beylin, who claims that she was swayed by the 'epic sweetness with which his voice and gestures are reverberating' (BEYLIN 1947). Moreover, the efficacious use of music in the production is also corroborated by Waclaw Borowy, a renowned Polish literary historicist of the period who published a glowing review of the production. According to Borowy, music facilitates the harmony of the play and helps the audience to imagine the tonal life of the island (BOROWY 1947).

In a 2016 academic article examining Shakespeare productions in Poland under the Communist regime, Kujawińska-Courtney (2016: 24) claims that the post-war artists' celebration of freedom ceased in 1947 when the Communist system began to operate in full swing. However, this same year also saw the inauguration of the National Shakespeare Festival, an event which proves for Kujawińska-Courtney that the Bard was 'a trustworthy companion of Polish culture amidst the encroaching Communist enslavement' (KUJAWIŃSKA-COURTNEY 2016: 24). Interestingly, Schiller's The Tempest won the festival, however, there was no sign of the production that would unanimously corroborate the theme Kujawińska-Courtney argues for in her account of the contest. According to the scholar, the festival 'was a sign of courage and defiance. It was not only an attempt to demonstrate Poland's connection to Europe, while at the same time subverting Marxist ideology and Soviet culture, but also an attempt to reclaim the Polish theatre's pre-war international status' (KUJAWIŃSKA-COURTNEY 2016: 24). Yet, if one were to put the prize-winner under scrutiny and dissect several components

19 'Teatr monumentalny cechuje rozmach inscenizacyjny, dażenie do ciagtego przekraczania ograniczeń materialnych, technicznych, wykonawczych.' (POPIEL 1995: 233)

20 The recordings of Schiller's Tempest were retrieved from the Polish National Digital Archives on 30.07.2019. File signature in the catalogue: 33-P-1034.

21 'Patetyzm, hieratyczność, posagowość - to pojęcia bliskie aktorstwu w teatrze monumentalnym.' (POPIEL 1995: 238) 
constituting the production, it becomes apparent that Schiller's play was not as close to a bold demonstration as Kujawińska-Courtney would have it. Rather the monumentality of the play - with its formative idea of a revolution both of the proletariat and in terms of the Romantic spirit of revolution - remain as arguable as it ever was. Taking into consideration the often-unresolved attempts at defining what the monumental theatre was, it seems evident that the scholar has not considered Schiller's complicated intellectual indebtedness to Catholicism, Romanticism, and Marxism.

However, Kujawińska-Courtney directs our attention to the important discussion initiated by Polish Shakespeare scholars concerning the choice of translations for new productions. She argues that the dispute was in fact one of the major reasons to organize the festival. ${ }^{22}$ Again, Schiller's production of The Tempest both illustrates this preoccupation with new translations, as well as undermines the significance. Although the award-winning staging of The Tempest did employ a new translation, the quality of which left much to be desired, as it lacked proper editing. Furthermore, Czesław Jastrzębiec-Kozłowski, ${ }^{23}$ the author of the translation, completed the translation in about a month as the Second World War was drawing to a close. The numerous faults of the translation (HELSZTYŃSKI 1964: 314-326) are only magnified when it becomes apparent that the actual playscript significantly departed from the new translation and featured large portions of the canonical $19^{\text {th }}$ century translation by Leon Ulrich and even songs written by the director himself. ${ }^{24}$ Thus amalgamated, Kozłowski's rendition of Shakespeare's utopia - instead of breathing fresh air into the idiolect of Polish postwar Shakespeare - seems to have resuscitated not only the language of the pre-war period, but also elements of the Romanticised style of the plays from the earlier century.

Further doubts regarding Schiller's intentions behind the production become evident if we take a brief look at his biography during the interim. According to the Polish director and writer Kazimierz Braun, Schiller 'played a significant role in subordinating the theatrical milieu to the Communists and Sovietising Polish theatre' by e.g. introducing several prominent writers of socialist realism such as Wolf, Gorky, Hay, and Ivanov (BRAUN 1994: 71-72). Already in 1945 Schiller 'began making a career within the new regime' and therefore 'won much support' from the authorities (BRAUN 1994: 71-72). Notwithstanding Schiller's subsequent revolt against the Communist regime in

\footnotetext{
22 'The Festival was probably inspired by Wacław Borowy's article "According to which translation are we to act Shakespeare?" (W jakim przektadzie grać Szekspira?), published in the newly created monthly Teatr. His comparative study of the most eminent Polish translations of Shakespeare's texts stressed their role in both pre- war Poland and post-war theatre.' (KUJAWIŃSKA-COURTNEY 2016: 24)

23 Czesław Jastrzębiec-Kozłowski (1894-1956) was one of the first translators of Shakespeare's plays during the post-war period. His translation of The Tempest, however, was heavily criticized in the 1960s for its many inaccuracies. The 'lapsus linguae anglicae' (HELSZTYŃSKI 1964: 322) featured distorted metaphors and striking misinterpretations, and Kozłowski was also guilty of employing a somewhat archaic and uncommon register. His translation was found worthy only in 1999 when Anna Staniewska, an editor of the canonical editions of Polish Shakespeare, deemed that the language of Kozłowski's translation was caught in between the idiom of Polish interwar poetry and an attempt to rejuvenate Shakespeare. Staniewska thus provided it with the editorial care it has needed since 1945 (STANIEWSKA 1998: 638-639).
}

For more on Schiller's additions, see (DUNIEC 1998). 
the early 1950s, it cannot be denied that his festival production can be viewed as at least a play allowed and nurtured by obedience if not an act of subservience to the regime. Jan Kott's analysis of the staging - to some an example of genuine criticism, to others clearly a political condemnation - offers some interesting comments on the contemporary perception of the production:

The passionate and fierce The Tempest disappeared, leaving behind only one of its implications: rationality and optimism. Prospero turned into an eminent, enlightened monarch or even an 18th century reformist philosopher, who contrary to the author (Shakespeare is the author, alas), mercifully invites Caliban on board the ship departing from the island [...] Schiller rendered Shakespeare the renaissance innovator a mere bourgeois solidarist. ${ }^{25}$ (KOTT 1955: 68)

Leaving aside Kott's own somewhat complicated relationship with early Communism, it seems clear that Schiller's utopian interpretation struck the reviewer as both naïve as well as incapable of confronting recent atrocities of the Second World War in shifting its focus to the visual, monumental aspects of the staging. What is more, Kott's observations may indicate that Schiller's vision was redirected from a mutinying utopia-to-come to an affirmation of an already-achieved utopian paradise. It is here, perhaps, that Cioran's fascination with the impossible becomes Schiller's fascination with the attainable. Here Caliban has lost his role as a revolutionary and has become instead an obedient follower, exemplifying his inherently subservient position indicated earlier by Thomas Bulger. In other words, Schiller appropriates the play to suit his political vision and individual ambitions strives to inscribe The Tempest with a message it cannot offer.

And yet even Kott admitted the 'very beautiful and impressive' (KOTT 1955: 68) nature of the production. The goal 'to reclaim Polish theatre's pre-war international status' (KUJAWIŃSKA-COURTNEY 2016: 24) was indeed apparent in Schiller's staging, which many critics saw as a synthesis of his claims as regards the monumental theatre from the interwar period (CSATÓ 1968: 483). However, the status of the theatre derives not only from its aesthetics, but also from its social role and responsiveness to historical circumstances. In this sense, Schiller's The Tempest apparent recuperative status pales in insignificance compared with his pre-war production of the 1938 play staged in cooperation with Jewish Folks un Jungt-Teater in Łódź. Certainly, the act of solidarity with the Jewish theatre in times of growing antisemitism was not the status quo of Polish pre-war theatre as a whole. Nonetheless, it can be argued that it ought to be seen as a vital constituent of Schiller's attitude towards theatre in the pre-war period. According to Gabriela Łazarkiewicz, not only the fact of cooperation is worth admiration, but also the choice of the play:

25 'Z namiętnej i groźnej Burzy ostat się w tym przedstawieniu tylko jeden z jej sensów: racjonalistyczny i optymistyczny. Prospero stat się zacnym oświeconym monarcha czy też nawet postepowym filozofem XVIII wieku, który wbrew autorowi (autorem jest, niestety, Szekspir) taskawie zaprasza Kalibana na poktad okrętu opuszczajacego wyspe [...] A mimo to przedstawienie jest bardzo piękne i imponujace.' (KOTT 1955: 68) 
In the midst of the impending danger, any successful artistic collaboration between Polish and Jewish theatres would have carried a symbolical value for obvious political reasons, but choosing The Tempest was by no means accidental. Although Schiller was not the one to choose the play, he emphasised the political dimension of Shakespeare's masterpiece [...] It is clear that Schiller's intention was to explore the timelessness of The Tempest and to make it seem as contemporary and relevant as possible [emphasis added]. (ŁAZARKIEWICZ 2013: 46)

Comparing various reviews of the 1938 and 1947 production, ${ }^{26}$ one can observe that the critics paid attention to one particular line in the play, namely Stephano's 'Thought is free' he utters at the conclusion of Act III, Scene 2 (SHAKESPEARE 2011: 253). In both productions Schiller gave the line to Ariel and adapted it into a refrain with which the former slave of Sycorax ripostes Stephano's, Trinculo's, and Caliban's 'Flout'em and scout'em / And scout'em and flout'em' (SHAKESPEARE 2011: 253). The liberating force of this amendment, seemingly linking both productions, seems to encapsulate the character of Schiller's thwarted effort - in his striving to reconstruct the grandeur of the pre-war production he precipitously equals the significance of a heartfelt antiSemitic declaration with false hopes spurred on by the empty promises of the new regime. It is, thus, even more perplexing that an artist so conscious of the weight of the pre-war production not only did not allude to it in 1947, but also failed to recognise, or perhaps ignored, the play's potential to imbue it with relevant political messages during the interim. ${ }^{27}$

One of the possible explanations is Schiller's somewhat varying interpretation of the play. Łazarkiewicz claims that the director understood The Tempest in two separate ways. On one hand, '[i]t may seem that Schiller saw Caliban as a warrior, the Spartacus-like figure of theatre held captive by Prospero's magic and gathering his strength for a rebellion' (EAZARKIEWICZ 2013: 49). On the other, 'the main idea behind Schiller's staging of The Tempest was to show the triumphing rationalism of Prospero' (ŁAZARKIEWICZ 2013: 50-51). Bearing in mind Kott's review of the production, it appears that Schiller decided to reconcile these two readings in his 1947 staging as can be evidenced by the doubled stage design and repeated amendments of the text in the playscript (DUNIEC 1998: 129)..$^{28}$

26 See (PEIPER 1947) and the reviews of the 1938 production quoted in (TIMOSZEWICZ 1992).

27 It is, however, crucial to acknowledge that Schiller's 1946 staging of Stefan Otwinowski's drama Wielkanoc (Easter) - a play that dealt with the relationship between Jews and Poles during the Second World War - was a production that testified to the director's unbroken moral compass.

28 As Łazarkiewicz indicates, the 1938 production never reconciled Schiller's contradictory interpretations: 'According to Csató, it made the message of the play ambiguous and the final scene with Prospero holding Caliban in a forgiving gesture was designed to reconcile these two opposing concepts' (EAZARKIEWICZ 2013: 51). Additionally, the response of the Jewish intellectuals added another interpretative layer onto the play. Łazarkiewicz points out that for the Jewish audience 'The Tempest became a parable about the good mage Prospero harassed by Caliban, a dark monster who knows that if he wants to render the mage defenceless, he has to burn his books. In other words, Schiller's The Tempest told the story of the Jewish nation tormented by Nazism, a system that wants to wipe off the face of the Earth not only Jews, but also all of their cultural heritage' (ŁAZARKIEWICZ 2013: 52). 


\section{Conclusion}

The aim of this article was to assess the available sources surrounding the 1947 production as well as relevant elements of Schiller's biography and his theatrical concepts. Within this somewhat narrow consideration of the director's oeuvre, the emphasis of the paper was placed on various reactions to the play that might have distorted the significance of Schiller's endeavour. The conflicting example of 1938 production of The Tempest - supported largely by the contemporary recognition - showed not only the Polish director's unequivocal engagement with the most consequential issues of the time, but also his rather neglectful re-appropriation (or rather lack thereof) of the playscript adjustments and stage design formulas in The Tempest of 1947.

Inevitably, time and history leave the sources more difficult to obtain, however, evidence from the 1947 production render the discussion at least slightly less intangible. Czesław Jastrzębiec-Kozłowski and his translation from the period can on the one hand be seen as a vibrant but finally inferior attempt to renew the post-war Shakespeare idiom. On the other hand, the language of the interwar period with which it thrummed may have brought back the memories of the pre-war theatre for the interim audience. Nonetheless, there can be no denying that the liberating act of reclaiming the national language after five years of anguish and silence, should be ascribed to Schiller's idea of employing Kozłowski's translation.

On a philosophical level, Schiller seems to have ignored Shakespeare's ironic judgement of utopia, a decision which in consequence reduced the Polish director from Prospero's apprentice to a probationer of Gonzalo, as the old servant's utopic vision of the island 'is at once noble, Romantic, and absurd' (BULGER: 40). This assertion appears to resonate with Schiller's multifarious interpretations of the play. The Romantic aspect that Schiller shares with Gonzalo refers to the former's theory about monumental theatre, which, as we have seen, was an attempt to encompass numerous aspects of art, and thus drew on so many sources and tendencies that perhaps it exceeded the director's capacity to keep up with his own postulates.

What is more, Gonzalo's fascination with the island provides only further examples of Schiller's involuntary indebtedness to the king's advisor. The naïve optimism with which King Alonso's advisor introduces Act II serves as an excellent metaphor for Schiller's attitude, i.e. stepping into the interim with a stubborn and quite limited scope of vision. This somewhat therapeutic attitude might also reveal the director's way of coping with his traumatic episode in Auschwitz. In Act II, Scene 1, Gonzalo's recurring comment on their 'garments being, as they were ... hold[ing] notwithstanding their freshness and gloss, being rather new-dyed than stained with salt-water' (SHAKESPEARE 2011: 77), a remark ignored by Sebastian and Antonio, can be interpreted in terms of Schiller's refusal to reflect upon the tragedy of the Second World War and his decision instead to desperately cling to the newly established political paradigm of the Soviet regime.

It may also be that for Schiller a utopia was on its way towards realisation when the Communists seized the power after the Second World War. Moreover, it can be argued, 
that the director dulled the edge of Shakespeare's irony because he deemed it no longer necessary to poke holes in a reality attempting to heal its fatal wounds. Whatever the case, despite its success during the National Shakespeare Festival, Schiller's Tempest seems like an empty vessel with its meanings remaining stubbornly on the surface and its inner substance hollowed out by political compliance.

\section{Bibliography}

BEYLIN, Karolina. 1947. 'Burza' Szekspira wystawiona przez Państwowy Teatr Wojska Polskiego [Shakespeare's The Tempest staged at the National Theatre of the Polish Army]. Express Wieczorny 204 (1947): 4.

BOROWY, Wacław. 1947. Czarująca 'Burza' [An Enchanting 'Tempest']. Tygodnik Powszechny 33 (1947): 9.

BRAUN, Kazimierz. 1994. Teatr Polski (1939-1989): obszary wolności - obszary zniewolenia [Polish Theatre (1939-1989): Domains of Freedom - Fomains of Subjugation]. Warszawa: Wydawnictwo Naukowe Semper, 1994.

BULGER, Thomas. 1994. The Utopic Structure of The Tempest. Utopian Studies 5 (1994): 1: 38-47. CETERA, Anna. 2012. Wstęp [Introduction]. In William Shakespeare. Burza [The Tempest]. Transl. by Piotr Kamiński. Warszawa: W.A.B., 2012: 9-51.

CHOJNACKA, Anna. 2015. Leon Schiller w Polsce Ludowej 1946-1954 [Leon Schiller in Polish People's Republic 1946-1954]. Warszawa: Instytut Sztuki PAN, 2015.

CIORAN, Emil. 2015. History and Utopia. Transl. by Richard Howard. New York: Arcade Publishing, 2015.

CSATÓ, Edward. 1968. Leon Schiller. Warszawa: Państwowy Instytut Wydawniczy, 1968.

DUNIEC, Krystyna. 1998. Kaprysy Prospera [The Caprices of Prospero]. Warszawa: Oficyna Wydawnicza Errata, 1998.

FIK, Marta. 2000. Polski teatr monumentalny - cóż to znaczy? (próba podsumowania) [Polish Monumental Theatre - What Does It Mean? (An Attempt at a Conclusion)]. In Lidia Kuchtówna and Jan Ciechowicz (eds.). W kregu teatru monumentalnego [Within the Circle of Monumental Theatre]. Warszawa: Instytut Sztuki PAN, 2000: 197- 202.

HELSZTYŃSKI, Stanisław. 1964. Moje Szekspiriana [My Shakespearianas]. Warszawa: Państwowy Instytut Wydawniczy, 1964.

KARREMANN, Isabel and Erica SHEEN (eds.). 2016. Shakespeare in Cold War Europe. Conflict, Commemoration, Celebration. London: Palgrave Macmillan UK, 2016.

KOTT, Jan. 1955. Jak wam sie podoba [As You Like It]. Warszawa: Państwowy Instytut Wydawniczy, 1955.

KOTT, Jan. 1992. Pteć Rozalindy [The Gender of Rosalinda]. Kraków: Wydawnictwo Literackie, 1992.

KOTT, Jan. 1990. Szekspir wspótczesny [Shakespeare, Our Contemporary]. Kraków: Wydawnictwo Literackie, 1990.

KRASIŃSKI, Edward. 2000. Głosy w dyskusji [Disputing Standpoitns]. In Lidia Kuchtówna and Jan Ciechowicz (eds.). W kregu teatru monumentalnego [Within the Circle of Monumental Theatre]. Warszawa: Instytut Sztuki PAN, 2000: 205-206. 
KUCHTÓWNA, Lidia. 2000. Nurt polskiego teatru monumentalnego. Zarys historyczny [The Trends of Polish Monumental Theatre. A Historical Outline]. In Lidia Kuchtówna and Jan Ciechowicz (eds.). W kregu teatru monumentalnego [Within the Circle of Monumental Theatre]. Warszawa: Instytut Sztuki PAN, 2000: 16-23.

KUJAWIŃSKA-COURTNEY, Krystyna. 2016. Celebrating Shakespeare under the Communist Regime in Poland. In Erica Sheen and Isabel Karremann (eds.). Shakespeare in Cold War Europe. Conflict, Commemoration, Celebration. London: Palgrave Macmillan UK, 2016.

ŁAZARKIEWICZ, Gabriela. 2013. Caliban, thou art translated: The Metamorphoses of Caliban on the Polish Stage in the 20 $0^{\text {th }}$ and $21^{\text {st }}$ Centuries. MA Thesis. Sup. of Anna Cetera. University of Warsaw, 2013.

ŁAZARKIEWICZ, Gabriela. 2015. Holocaust a Búrka v Pol’sku. Inscenácie Leona Schillera (1938) a Krzysztofa Warlikowského [Holocaust and The Tempest in Poland. Staging of Leon Schiller (1938) and Krzysztof Warlikowsky]. In Jana Bžochová-Wild (ed. and trans.). Zrkadlá (pre) doby. Shakespeare v divadle strednej Európy. Bratislava: Vysoká škola múzických umení, 2015.

MICKIEWICZ, Adam. 1998. Literatura słowiańska [Slavic Literature]. Kurs trzeci [Course no. 3]. In Adam Mickiewicz. Dzieta. Wydanie Rocznicowe [Works. Anniversary Edition], Julian Maślanka (ed.). Warszawa: Czytelnik, 1998: 165-173.

MIŁOSZ, Czesław. 1983. The History of Polish Literature. Berkeley/London: University of California Press, 1983: 441-458.

PEIPER, Tadeusz. 1947. Po konkursie Szekspirowskim [In the Wake of the Shakespeare Festival]. Odrodzenie 34 (1947): 3.

POPIEL, Jacek. 1995. Dramat a teatr polski dwudziestolecia międzywojennego [Drama and Polish Theatre of the Interwar Period]. Kraków: Universitas, 1995.

ROGACKI, Henryk Izydor. 1995. Leon Schiller. Łódź: Wydawnictwo Łódzkie, 1995.

SCHILLER, Leon. 2004. Teatr demokracji ludowej 1946-1950/Leon Schiller [People's Democracy Theatre 1946-1950/Leon Schiller]. Warszawa: Instytut Sztuki PAN, 2004.

SCHILLER, Leon. 1961. Teatr ogromny [The monumental theatre]. Ed. by Anna Chojnacka and Jerzy Timoszewicz. Warszawa: Czytelnik, 1961.

SHAKESPEARE, William. 2011. The Tempest. Ed. by Virginia Mason Vaughan and Alden T. Vaughan. London: Bloomsbury Arden Shakespeare, 2011.

SHAKESPEARE, William. 1998. Burza [The Tempest]. In Anna Staniewska (ed.). Dwanaście dramatów [Twelve Plays]. Vol. 3. Warszawa: Świat Książki, 1998: 497-605.

STŘÍBRNÝ, Zdeněk. 2000. Shakespeare and Eastern Europe. Oxford: Oxford University Press, 2000.

TERLECKI, Tymon. 2000. Polski teatr monumentalny [Polish Monumental Theatre]. In Lidia Kuchtówna and Jan Ciechowicz (eds.). W kręu teatru monumentalnego [Within the Circle of Monumental Theatre]. Warszawa: Instytut Sztuki PAN, 2000: 9-11.

TIMOSZEWICZ, Jerzy. 1989. Komunista trochę - i romantyk [A Romantic - and a Tad Communist]. Dialog 6 (1989): 135-142.

TIMOSZEWICZ, Jerzy. 1992. Czarująca 'Burza' [An Enchanting 'Tempest']. Tygodnik Pamiętnik teatralny 1/4 (1992): 439-452.

VIERA, Fátima. 2010. The Concept of Utopia. In Gregory Claeys (ed.). The Cambridge Companion to Utopian Literature. Cambridge: Cambridge University Press, 2010: 3-27. 


\section{Mgr. Przemysław Pożar}

University of Warsaw,

Krakowskie Przedmieście 26/28, 00-927, Warszawa, Poland

p.pozar@student.uw.edu.pl

Przemysław Pożar is a PhD student at the University of Warsaw and a member of the research group compiling the e-repository of Shakespeare translations into Polish in the $20^{\text {th }}$ and $21^{\text {st }}$ century. 
